\title{
Rates of Urea Synthesis in the Human Newborn: Effect of Maternal Diabetes and Small Size for Gestational Age
}

\author{
SATISH C. KALHAN \\ Department of Pediatrics, Case Western Reserve University, School of Medicine, Cleveland, Ohio 44106
}

\begin{abstract}
The rates of urea synthesis and glucose turnover were quantified during fasting using $\left[{ }^{15} \mathrm{~N}_{2}\right]$ urea and $\left[6,6^{2} \mathrm{H}_{2} \mid\right.$ glucose tracers with the prime constant rate infusion technique in 33 infants: 19 normal infants, 10 infants of diabetic mothers (IDM), and four small for gestational age (SGA) infants born at term gestation. All infants were studied during fasting $4 \mathrm{~h}$ after their last feed. Eleven normal infants and six IDM were studied soon after birth before any feeding. The rate of urea synthesis in normal infants was $5.84 \pm 2.0 \mathrm{mg}$ of nitrogen $(\mathrm{N}) / \mathrm{kg} \cdot \mathrm{h}^{-1}$ or $3.5 \mu \mathrm{mol}$ of urea $/ \mathrm{kg} \cdot \mathrm{min}^{-1}$. The rate was slightly higher in IDM (7.09 $\left.\pm 3.0 \mathrm{mg} \mathrm{N} / \mathrm{kg} \cdot \mathrm{h}^{-1}\right)$ and lower in SGA infants $\left(4.59 \pm 1.22 \mathrm{mg} \mathrm{N} / \mathrm{kg}^{\cdot} \mathrm{h}^{-1}\right)$; however, the differences were not statistically significant. No differences in urea synthesis were observed between infants studied soon after birth and those studied after initiation of feeding. The rate of appearance of glucose was lower in IDM infants studied during the first $6 \mathrm{~h}$ after birth (IDM 19.62 \pm 2.14 $\mu \mathrm{mol} / \mathrm{kg} \cdot \mathrm{min}^{-1}$, normal infants $24.03 \pm 4.05 \mu \mathrm{mol} /$ $\left.\mathrm{kg} \cdot \mathrm{min}^{-1}, p=0.01\right)$. However, rate of appearance of glucose in IDM infants studied between 17 and $20 \mathrm{~h}$ after birth was similar to that in normal infants. Rate of appearance of glucose was lower (not significantly) in SGA infants $\left(17.7 \pm 3.3 \mu \mathrm{mol} / \mathrm{kg}^{\prime} \mathrm{min}^{-1}\right)$ as compared with normal infants. No correlation between rates of urea synthesis and glucose turnover was observed. These data show that newborn infants during fasting have an obligatory rate of protein oxidation of $\sim 0.87 \mathrm{~g} / \mathrm{kg} \cdot \mathrm{d}^{-1}$ and that maternal diabetes has no effect on it. The slightly lower rate of protein oxidation in SGA infants may be related to increased $N$ assimilation. (Pediatr Res 34: 801-804, 1993)
\end{abstract}

\section{Abbreviations}

\section{$\mathbf{N}$, nitrogen}

IDM, infants of insulin-dependent diabetic mothers

SGA, small for gestational age

AGA, appropriate for gestational age

$\mathrm{Ra}$, rate of appearance

Measurements of urea $\mathrm{N}$ excretion are performed to quantify nitrogen balance and rates of protein oxidation in infants and children. However, limited data are published in literature on the rates of urea synthesis or excretion in the human newborn. Previous data suggested that the rates of urea $\mathrm{N}$ excretion in the newborn infant may be much lower than those in the adults as

Received April 21, 1993; accepted July 13, 1993.

Correspondence: Satish Kalhan, M.D., Division of Neonatology, Rainbow Babies \& Childrens Hospital, 2101 Adelbert Rd., Cleveland, OH 44106.

Supported by Grants HD11089 and RR00210 from the National Institutes of Health. a consequence of active growth (1). A later study by Jones $e t$ al. (2) showed that the rates of urea $\mathrm{N}$ excretion in the urine of newborn infants were higher than previously suggested. Nevertheless, the urea excretion rate was much less than that estimated for the human fetus at term gestation by Gresham et al. (3). Inasmuch as urinary urea does not reflect the excretion of the total urea synthesized because of loss of urea by skin and possibly because of hydrolysis in the gut, the measurements of urea $\mathrm{N}$ excretion in urine will underestimate the actual rates of urea synthesis and therefore protein oxidation $(4,5)$. In fact, the rates of protein oxidation, as measured by oxidation rates of essential amino acids such as leucine $(6,7)$, suggest a much higher rate of protein oxidation in full-term newborn infants $\left(\sim 1.4 \mathrm{~g} / \mathrm{kg} \cdot \mathrm{d}^{-1}\right)$ as compared with those by the urea excretion rate from previous studies $\left(\sim 0.4 \mathrm{~g} / \mathrm{kg} \cdot \mathrm{d}^{-1}\right)$.

In the present study, the rates of urea synthesis were quantified by the tracer dilution technique, which will estimate the total rate of urea synthesis and therefore should provide an estimate of total protein oxidation. Normal full-term infants were studied during fasting, and the effect of maternal diabetes and intrauterine growth retardation on urea synthesis was examined. Because ureagenesis is considered a concomitant of gluconeogenesis from amino acids $(8,9)$, the rate of glucose turnover was also quantified simultaneously by tracer dilution to examine the relation between ureagenesis and glucose turnover.

\section{MATERIALS AND METHODS}

Urea and glucose kinetics were measured in 33 newborn infants during the first $3 \mathrm{~d}$ after birth. All infants were studied during fasting, either before the initiation of feeding soon after birth or $4 \mathrm{~h}$ after their last feeding. Nineteen were full-term, AGA infants (Table 1). Of these, 11 were studied soon after birth during the first $5 \mathrm{~h}$ and eight were studied after the feeding was started on the second or third day. They were fed commercial formula $60-70 \mathrm{~mL} / \mathrm{kg} \cdot \mathrm{d}^{-1}$ (Similac, Ross Laboratories, Columbus, $\mathrm{OH}$ ) or were breast fed. Of the 10 IDM, six were studied during the first $5 \mathrm{~h}$ after birth, and four were studied after the feedings were started on the second day. Four SGA infants were studied between 8 and $36 \mathrm{~h}$ after birth. All infants were born after an uncomplicated delivery, did not have any perinatal problems such as asphyxia or sepsis, and were cared for in the newborn nursery for normal infants. Written informed consent was obtained from one or both parents after the procedure was fully explained to them. The study protocol was reviewed and approved by the Institutional Committee on Investigations in Humans. The investigator was not responsible for the clinical care of the mothers or infants. All infants were studied in the Perinatal Clinical Research Center at Cleveland Metropolitan General Hospital in a study room maintained at $30^{\circ} \mathrm{C}$ and relative humidity of $40 \%$. Two i.v. 23 -gauge butterfly needles were placed, one each in the dorsum of the hand and the foot, to infuse the tracers and draw blood samples. The sampling site 
Table 1. Clinical characteristics of study infants $(n=33)(\text { mean } \pm S D)^{*}$

\begin{tabular}{lccccc}
\hline & $\begin{array}{c}\text { Birth weight } \\
(\mathrm{g})\end{array}$ & $\begin{array}{c}\text { Gestational age } \\
(\mathrm{wk})\end{array}$ & $\begin{array}{c}\text { Age at study } \\
(\mathrm{h})\end{array}$ & Males/females & $\begin{array}{c}\text { Delivery (vaginal/ } \\
\text { cesarean section) }\end{array}$ \\
\hline Normal infants & & & & & \\
$\quad$ Not fed $(n=11)$ & $3164 \pm 367$ & $39 \pm 1.3$ & $3 \pm 1$ & $6 / 5$ & $6 / 5$ \\
$\quad$ Previously fed $(n=8)$ & $3139 \pm 781$ & $40 \pm 1.9$ & $(8-72) \dagger$ & $3 / 5$ & $5 / 3$ \\
$\quad$ & & $38 \pm 1$ & $3 \pm 1$ & $3 / 3$ & $1 / 5$ \\
$\quad$ Not fed $(n=6)$ & $3612 \pm 611 \ddagger$ & $39 \pm 1$ & $(17-20) \dagger$ & $2 / 2$ & $3 / 1$ \\
$\quad \begin{array}{l}\text { Previously fed }(n=4) \\
\text { SGA infants }\end{array} \quad 3403 \pm 668 \ddagger$ & & & $2 / 2$ & $4 / 0$ \\
$\quad$ Previously fed $(n=4)$ & $2453 \pm 105 \ddagger$ & $41 \pm 0.6$ & $(8-33) \dagger$ & & \\
\hline
\end{tabular}

*All infants were studied during fasting. "Not fed" infants were studied soon after birth before any feeding. "Previously fed" infants were studied after the initiation of feeding; however, they had also fasted for $4 \mathrm{~h}$ before the start of the tracer infusion, which was continued for 4-5 $\mathrm{h}$.

† Range.

$¥$ Significantly different when compared with normal infants (analysis of variance, $p<0.01$ ).

was kept patent by infusion of normal saline at $2 \mathrm{~mL} / \mathrm{h}$ along with intermittent heparin saline flushes. Plasma glucose was monitored throughout the study to assure that no infant became hypoglycemic.

$\left[{ }^{15} \mathrm{~N}_{2}\right]$ urea, 99 atom \% ${ }^{15} \mathrm{~N}$, and $\left[6,6^{2} \mathrm{H}_{2}\right]$ glucose, 98 atom \% ${ }^{2} \mathrm{H}$, were obtained from Merck \& Co, Inc., Dorval, Canada. The tracers were prepared for i.v. infusion and were tested for sterility and pyrogenicity as described previously (10). Both tracers were infused simultaneously as a prime-constant rate infusion via an occlusive pump (Holter pump, Extracorporeal Medical Specialties, Inc., King of Prussia, PA). To achieve an early steady state, usually between 2 and $3 \mathrm{~h}$ for urea and $\sim 90 \mathrm{~min}$ for glucose, a priming dose of both tracers was given. For $\left[{ }^{15} \mathrm{~N}_{2}\right]$ urea, the bolus prime was $2 \mathrm{mg} / \mathrm{kg}$ body weight and the rate of constant infusion was $0.2 \mathrm{mg} / \mathrm{kg} \cdot \mathrm{h}^{-1}$. For $\left[6,6^{2} \mathrm{H}_{2}\right]$ glucose, the prime equaled 90 min of infusion or $2.7 \mathrm{mg} / \mathrm{kg}$ body weight, and the rate of constant infusion was $60 \mu \mathrm{g} / \mathrm{kg} \cdot \mathrm{min}^{-1}$. The tracers were infused for a period of 4-5 h. Twenty infants (10 normal infants, six IDM, and four SGA infants) also received $\left[{ }^{13} \mathrm{C}\right]$ lactate for lactate turnover studies (data reported separately). The rate of infusion was checked in each study gravimetrically at the end using the same needle and infusion system. Blood samples $(1.0 \mathrm{~mL})$ were drawn at 30 -min intervals in heparinized syringes. Sample size was reduced in smaller infants. Plasma was separated immediately by centrifugation at $\approx 4^{\circ} \mathrm{C}$ and stored at $-10^{\circ} \mathrm{C}$ for later analysis.

Assays. Plasma glucose was measured by a coupled enzymatic assay using hexokinase and glucose-6-phosphate dehydrogenase on an automated centrifugal system (Baker Instruments, Pleasantville, NY). Plasma urea $\mathrm{N}$ was measured on the same system by a coupled reaction using urease and glutamic dehydrogenase (10).

Plasma C-peptide levels were measured by a double antibody radioimmunoassay after extraction of the interfering antibodies by polyethylene glycol (11).

The ${ }^{2} \mathrm{H}$ enrichment of glucose was measured on an HP5985 gas chromatography mass spectrometry system (Hewlett-Packard, Palo Alto, CA) after the preparation of a pentacetate derivative, as described previously $(10,12)$. Electron impact ionization $(70 \mathrm{eV})$ was used and $\mathrm{m} / \mathrm{z} 98$ and 100 were monitored using selected ion monitoring. Standard glucose solutions of known enrichment were run simultaneously. For the measurement of $\left[{ }^{15} \mathrm{~N}_{2}\right]$ urea enrichment, 2-hydroxypyrimidine derivative of urea was prepared as described by us previously (13). Standard urea solutions of known enrichment were run simultaneously.

The Ra of glucose and urea were calculated, assuming a single compartment model, during steady state by tracer dilution (14): $\mathbf{R a}=[(100 / \mathrm{Ep})-1] \times \mathbf{I}$, where $\mathbf{R a}$ is the rate of appearance in $\mu \mathrm{mol} \mathrm{or} \mathrm{mg} / \mathrm{kg} \cdot \mathrm{min}^{-1}, \mathrm{Ep}$ is the enrichment of the tracer in the plasma, and I is the rate of infusion of the tracer in $\mu \mathrm{mol}$ or $\mathrm{mg} /$ $\mathrm{kg} \cdot \mathrm{min}^{-1}$. This equation assumes $100 \%$ enrichment of the infused tracers. The standard curves of known enrichment were also prepared assuming $100 \%$ enrichment.
All data are reported as mean \pm SD. Statistical analyses were performed on an IBM personal computer using SPSS software (SPSS Inc., Chicago, IL). Groups were compared using analysis of variance and pair-wise comparisons were carried out using Duncan's multiple range test.

\section{RESULTS}

All infants were born at term gestation, were stable, and did not have any perinatal problems (Table 1 ). As anticipated, the IDM were heavier and the SGA infants were lighter compared with AGA infants (analysis of variance, $p<0.01$ ). All infants were studied during fasting. The infants designated "not fed" had not received any feeding since birth and were studied at an average of $3 \mathrm{~h}$ after birth. The previously fed infants had received their initial formula or breast feeding; however, full feeding had not yet been established. These infants also fasted, i.e. skipped one meal. Therefore, the urea and glucose kinetics were measured at approximately $8 \mathrm{~h}$ after the last meal. As shown by us previously, such a fast would correspond to approximately 16-18 h of fasting for an adult (15).

The plasma glucose concentrations were similar in the three groups (Table 2). No significant effect of initiation of feeding was observed in the normal infants or IDM. The urea $\mathrm{N}$ concentration was slightly lower in the SGA infants and higher in the IDM as compared with the normal infants. C-peptide concentrations were similar in normal infants and IDM, reflecting good control of maternal metabolism.

Glucose and urea turnover rates are shown in Tables 2 and 3. Isotopic steady state was observed in all infants between $2 \frac{1}{2}$ and $3 \mathrm{~h}$. The $\mathrm{Ra}$ of glucose was lower in IDM as compared with normal infants soon after birth $(p=0.01)$; however, in the infants studied later, the glucose $\mathrm{Ra}$ was similar in the two groups. In the SGA infants, glucose Ra was lower (not significantly) than that in normal infants. The rate of urea synthesis in the term AGA infants was $5.6 \mathrm{mg} \mathrm{N} / \mathrm{kg} \cdot \mathrm{h}^{-1}$ (range $2.4-8.9 \mathrm{mg} \mathrm{N} / \mathrm{kg} \cdot \mathrm{h}^{-1}$ or $\left.1.4-5.3 \mu \mathrm{mol} / \mathrm{kg} \cdot \mathrm{min}^{-1}\right)$. Urea synthesis was slightly higher in the infants studied after the initiation of feeding. Of interest is the higher rate of urea synthesis in the IDM and the lower rate in the SGA infants. However, none of these measurements were significantly different from those in normal infants. Estimated protein oxidation from these data will correspond to $0.87 \mathrm{~g} / \mathrm{kg}$. $\mathrm{d}^{-1}$ for the term AGA infants, $1.1 \mathrm{~g} / \mathrm{kg} \cdot \mathrm{d}^{-1}$ for the IDM, and 0.7 $\mathrm{g} / \mathrm{kg} \cdot \mathrm{d}^{-1}$ for the SGA infants.

No correlation was observed between the rates of urea synthesis and the rate of glucose appearance, either in individual groups or in all the groups collectively.

\section{DISCUSSION}

The results of the present study show that the rate of urea synthesis or protein oxidation in the full-term infant in the period immediately after birth corresponds to $5.6 \mathrm{mg} \mathrm{N} / \mathrm{kg} \cdot \mathrm{h}^{-1}$ or 0.8 
Table 2. Glucose kinetics in newborn infant (mean $\pm S D$ )

\begin{tabular}{|c|c|c|c|c|}
\hline & $\begin{array}{c}\text { Glucose } \\
(\mathrm{mmol} / \mathrm{L})\end{array}$ & $\begin{array}{c}\text { C-peptide } \\
(\mu \mathrm{g} / \mathrm{L})\end{array}$ & $\begin{array}{c}{\left[{ }^{2} \mathrm{H}_{2}\right] \text { glucose }} \\
\text { infusion rate } \\
\left(\mu \mathrm{mol} / \mathrm{kg} \cdot \mathrm{min}^{-1}\right)\end{array}$ & $\begin{array}{c}\text { Glucose Ra } \\
\left(\mu \mathrm{mol} / \mathrm{kg} \cdot \mathrm{min}^{-1}\right)\end{array}$ \\
\hline \multicolumn{5}{|l|}{ Normals } \\
\hline Not fed* (11) & $3.11 \pm 0.51$ & $0.81 \pm 0.29$ & $0.178 \pm 0.06$ & $24.03 \pm 4.05$ \\
\hline Previously fed* (8) & $2.80 \pm 0.80$ & $\begin{array}{c}0.78 \pm 0.24 \\
(n=7)\end{array}$ & $0.224 \pm 0.077$ & $23.34 \pm 6.45$ \\
\hline \multicolumn{5}{|l|}{ IDM } \\
\hline $\begin{array}{l}\text { Previously fed* (4) } \\
\text { SGA }\end{array}$ & $3.62 \pm 1.37$ & $1.12 \pm 0.40$ & $0.150 \pm 0.013$ & $28.88 \pm 9.90 \ddagger$ \\
\hline Previously fed* (4) & $3.46 \pm 0.43$ & $0.64,0.58$ & $0.147 \pm 0.007$ & $17.71 \pm 3.34$ \\
\hline
\end{tabular}

* See Table 1 for explanation.

$+p=0.01$ compared with fasting normal infants.

$\ddagger p=0.05$ compared with fasting IDM ( 0.02 by WRS test).

Table 3. Urea kinetics in fasting newborn infant (mean $\pm S D$ )

\begin{tabular}{|c|c|c|c|c|}
\hline & \multirow{2}{*}{$\begin{array}{c}\text { BUN } \\
(\mathrm{mmol} / \mathrm{L})\end{array}$} & \multirow{2}{*}{$\begin{array}{c}{\left[{ }^{15} \mathrm{~N}_{2}\right] \text { urea }} \\
\text { infusion rate } \\
\left(\mu \mathrm{mol} / \mathrm{kg} \cdot \mathrm{h}^{-1}\right)\end{array}$} & \multicolumn{2}{|c|}{ Urea N Ra } \\
\hline & & & $\mathrm{mg} \mathrm{N} / \mathrm{kg} \cdot \mathrm{h}^{-1}$ & $\mu \mathrm{mol} / \mathrm{kg} \cdot \mathrm{min}^{-1}$ \\
\hline \multicolumn{5}{|l|}{ Normal } \\
\hline Not fed* (11) & $3.36 \pm 0.66$ & $3.44 \pm 0.65$ & $5.58 \pm 1.96$ & $3.32 \pm 1.17$ \\
\hline Previously fed* (8) & $3.08 \pm 1.27$ & $3.53 \pm 0.30$ & $6.20 \pm 2.13$ & $3.69 \pm 1.27$ \\
\hline \multicolumn{5}{|l|}{ IDM } \\
\hline Not fed* $(6)$ & $3.82 \pm 0.58$ & $3.89 \pm 0.46$ & $6.93 \pm 1.37$ & $4.13 \pm 0.82$ \\
\hline \multicolumn{5}{|l|}{ SGA } \\
\hline Previously fed* (4) & $2.37 \pm 0.86$ & $3.79 \pm 2.11$ & $4.60 \pm 1.23$ & $2.74 \pm 0.73$ \\
\hline
\end{tabular}

* See Table 1 for explanation.

$\mathrm{g} / \mathrm{kg} \cdot \mathrm{d}^{-1}$ protein. Inasmuch as the babies had not been fed and were examined within $5 \mathrm{~h}$ of birth, these data represent the oxidation of endogenous protein. In addition, if one assumes that protein metabolism after birth is a continuum of fetal protein metabolism, these data may be the closest approximation of the rate of oxidation of protein by the human fetus at term gestation. These data are much lower than those estimated by Gresham $e t$ al. (3) based on the umbilical artery-vein gradient of urea in the human fetus at term gestation. The differences may be related to the fact that Gresham et al. only measured umbilical artery and vein differences at delivery and calculated urea production from the known clearance rate of urea by the sheep placenta. In the present study, the rate of urea synthesis was measured directly by tracer dilution. The ability of the human fetal liver to synthesize urea has been demonstrated as early as $12-16$ wk of gestation (16), and significant activity of hepatic urea cycle enzymes has been measured at $13 \mathrm{wk}$ of gestation (17). The fetus achieves $90 \%$ of the adult urea cycle enzyme activity by 36 wk of gestation. Thus, the human newborn at term has almost the full adult potential to synthesize urea.

The rate of protein oxidation is often quantified in newborn infants as well as in adults to estimate the $\mathrm{N}$ loss and, indirectly, $\mathrm{N}$ accretion and dietary protein requirements. The commonly used methods involve measurements of urinary $\mathrm{N}$ excretion (18, 19) or tracer isotope methods of quantifying oxidation to $\mathrm{CO}_{2}$ of an essential amino acid $(6,7)$. The measurement of urinary $\mathrm{N}$ excretion rate is particularly difficult in infants and children because of the problems of accurate and complete collection of urine. In addition, it does not include nonurinary losses of $\mathrm{N}$, e.g. skin and gut, does not include loss of urea as a result of hydrolysis in the gut (if any), and requires adjustments for the change in body urea pool size $(4,5,20)$. The tracer carbon oxidation method also has the disadvantage of requiring the accurate measurement of the rate of carbon dioxide production, estimation of bicarbonate retention, and the effect of exchange of tracer carbon, resulting in a loss of tracer. In contrast, the $\left[{ }^{15} \mathrm{~N}_{2}\right.$ ] urea tracer dilution method includes all the urea synthesized by liver or appearing in plasma, irrespective of its source or the mechanism of loss. The use of doubly labeled tracer and measurement of the dilution of $(\mathrm{m}+2)$ species results in inclusion of all newly synthesized urea $(10,21,22)$. Finally, the tracer $(m+2)$ species do not include any recycled tracer, which will form only $(m+1)$ species. As stated above, the tracer method includes all the urea appearing in plasma, irrespective of the source, and thus will also include dietary urea, particularly in the breast-fed infant because of the presence of a significant amount of urea $\mathrm{N}$ in breast milk (23-25). However, in the present study because all the infants were fasting, the contribution of urea $\mathrm{N}$ from diet was expected to be nil. Therefore, the present estimates of urea synthesis represent the best approximation of the synthesis of urea or protein oxidation the newborn infants.

Only one other study has quantified rates of urea synthesis in newborn infants (26). Wheeler et al. (26), in four infants admitted to surgical intensive care units, by using orally administered $\left[{ }^{15} \mathrm{~N}^{15} \mathrm{~N}\right]$ urea and measuring ${ }^{15} \mathrm{~N}$ enrichment in urinary urea, estimated the urea synthesis rate to be $17.3 \mathrm{mmol} \mathrm{N} / \mathrm{kg} \cdot \mathrm{d}^{-1}$ or $12.0 \mu \mathrm{mol}$ of urea $\mathrm{N} / \mathrm{kg} \cdot \mathrm{min}^{-1}$, a rate considerably higher than that reported here. These differences may be related to the clinical condition of the infants, because all infants in our study were clinically well and had no perinatal problems. In addition, we studied infants during fasting, whereas the study population of Wheeler et al. was examined during feeding.

Other studies have quantified protein oxidation by measuring the rate of urea excretion or by the oxidation of essential amino acids. Pencharz et al. (27) estimated the obligatory loss of $\mathrm{N}$ in one full-term and six preterm infants from the regression of $\mathrm{N}$ balance and $\mathrm{N}$ intake. They estimated the total obligatory $\mathrm{N}$ loss to be $145 \mathrm{mg} \cdot \mathrm{kg}^{-1} \cdot \mathrm{d}^{-1}$ or $0.9 \mathrm{~g}$ protein $\mathrm{kg}^{-1} \cdot \mathrm{d}^{-1}$, a rate similar to the measurements in the present study. Estimates of protein oxidation in full-term infants using $\left[1-^{13} \mathrm{C}\right]$ leucine by us were $\sim 1.4 \mathrm{~g} / \mathrm{kg} \cdot \mathrm{d}^{-1}$, which is much higher than that in the present study $(4,5,19,20)$. These differences may be related to the 
observation that urea cycle enzymes can be readily regulated to conserve $\mathrm{N}$. Furthermore, differences between protein oxidation measured by leucine tracer and that measured by urea excretion have also been observed under other physiologic circumstances. In only one study of adults, the rates of protein oxidation measured by $\left[1-{ }^{13} \mathrm{C}\right]$ leucine tracer using keto-isocaproic acid enrichment and those measured by urinary urea $\mathrm{N}$ excretion were similar (28). Thus, the difference in other circumstances may be related to the regulation of urea synthesis or lack of measurement of the true precursor pool for the oxidation of amino acid.

The similar rate of urea synthesis in IDM as compared with normal infants is of interest, particularly in view of the observation of Jahoor and Wolfe $(29)$ and others $(30,31)$ that glucose by itself or via its hormonal responses suppresses urea production. Our data may be related to the rigorous regulation of maternal metabolism so that these infants were no longer hyperinsulinemic. Finally, SGA infants synthesized less urea compared with the normal infants, although the differences were not statistically significant and the numbers of SGA infants studied were too few to draw a conclusion. The lower rate of urea synthesis in SGA infants may be related to the increased accretion of $\mathrm{N}$ as demonstrated in infants recovering from malnutrition (32). These data showed a decreased rate of urea excretion in infants recovering from malnutrition.

Because the major source of glucose $\mathrm{Ra}$ at this stage of fasting is hepatic glycogen and because gluconeogenesis from amino acid is only a small contributor, the lack of correlation between glucose $\mathbf{R a}$ and urea synthesis rate was not surprising.

In summary, the present study quantified rates of urea synthesis during fasting in normal infants, IDM, and SGA infants. These data show that the rate of protein oxidation in newborn infants is $0.87 \mathrm{~g} / \mathrm{kg} \cdot \mathrm{d}^{-1}$. The rate was slightly higher in IDM and lower in SGA infants. Because these observations were made during fasting either soon after birth, before any feeding, or after initiation of feeding, these data should be considered to reflect obligatory protein oxidation.

\section{REFERENCES}

1. Barlow A, McCance RA 1948 The nitrogen partition in newborn infants' urine Arch Dis Child 23:225-230

2. Jones Jr MD, Gresham EL, Battaglia FC 1972 Urinary flow rates and urea excretion rates in newborn infants. Biol Neonate 21:321-329

3. Gresham EL, Simons PS, Battaglia FC 1971 Maternal-fetal urea concentration difference in man: metabolic significance. J Pediatr 79:809-811

4. Drotman RB, Freedland RA 1972 Citrulline metabolism in the perfused rat liver. Am J Physiol 222:973-975

5. Anonymous 1971 Urea metabolism in man. [editorial] Lancet 2:1407-1408

6. Denne SC, Rossi EM, Kalhan SC 1991 Leucine kinetics during feeding in normal newborns. Pediatr Res 30:23-27

7. Denne SC, Kalhan SC 1987 Leucine metabolism in human newborns. Am J Physiol 253:E608-E615

8. Krebs HA, Lund P, Stubbs M 1976 Interrelations between gluconeogenesis and urea synthesis. In: Hanson RW, Mahlman MA (eds) Gluconeogenesis: Its Regulation in Mammalian Species. John Wiley \& Sons, New York, pp 269-291

9. Mallette LE, Exton JH, Park CR 1969 Control of gluconeogenesis from amino acids in the perfused rat liver. J Biol Chem 244:5713-5723

10. Kalhan SC, Tserng K-Y, Gilfillan C, Dierker LJ 1982 Metabolism of urea and glucose in normal and diabetic pregnancy. Metabolism 31:824-833

11. Kuzuya H, Blix PM, Horwitz DL, Steiner DF, Rubenstein AH 1977 Determination of free and total insulin and C-peptide in insulin-treated diabetes. Diabetes 26:22-29

12. Patel D, Kalhan S 1992 Glycerol metabolism and triglyceride/fatty acid cycling in the human newborn: effect of maternal diabetes and intrauterine growth retardation. Pediatr Res 31:52-58

13. Tserng K-Y, Kalhan SC 1982 Gas chromatography/mass spectrometric determination of $\left[{ }^{15} \mathrm{~N}\right]$ urea in plasma and application to urea metabolism study. Anal Chem 54:489-491

14. Tserng K.Y, Kalhan SC 1983 Calculation of substrate turnover rate in stable isotope tracer studies. Am J Physiol 245:E308-E311

15. Denne SC, Kalhan SC 1986 Glucose carbon recycling and oxidation in human newborns. Am J Physiol 251:E71-E77

16. Raiha NCR, Suihkonen J 1968 Development of urea-synthesizing enzymes in human liver. Acta Paediatr Scand 57:121-124

17. Baig MMA, Habibullah CM, Swamy M, Hassan SI, Zaman T-Y, Ayesha Q Devi BG 1992 Studies on urea cycle enzyme levels in the human fetal liver at different gestational ages. Pediatr Res 31:143-145

18. Sulkers EJ, van Goudoever JB, Leunisse C, Wattimena JLD, Sauer PJJ 1992 Comparison of two preterm formulas with or without addition of medium. chain triglycerides (MCTs). I. Effects on nitrogen and fat balance and body composition changes. J Pediatr Gastroenterol Nutr 15:34-41

19. Rivera Jr A, Bell EF, Bier DM 1993 Effect of intravenous amino acids on protein metabolism of preterm infants during the first three days of life. Pediatr Res 33:106-111

20. Mitton SG, Calder AG, Garlick PJ 1991 Protein turnover rates in sick, premature neonates during the first few days of life. Pediatr Res 30:418-422

21. Matthews DE, Downey RS 1984 Measurement of urea kinetics in humans: validation of stable isotope tracer methods. Am J Physiol 246:E519-E527

22. Jahoor F, Wolfe RR 1987 Reassessment of primed constant-infusion tracer method to measure urea kinetics. Am J Physiol 252:E557-E564

23. Hambraeus L, Lonnerdal B, Forsum E, Gebre-Medhin M 1978 Nitrogen and protein components of human milk. Acta Paediatr Scand 67:561-565

24. Fomon SJ, Bier DM, Matthews DE, Rogers RR, Edwards BB, Ziegler EE Nelson SE 1988 Bioavailability of dietary urea nitrogen in the breast-fed infant. J Pediatr 113:515-517

25. Fomon SJ, Matthews DE, Bier DM, Rogers RR, Rebouche CJ, Edwards BB, Nelson SE 1987 Bioavailability of dietary urea nitrogen in the infant. J Pediatr 111:221-224

26. Wheeler RA, Jackson AA, Griffiths DM 1991 Urea production and recycling in neonates. J Pediatr Surg 26:575-577

27. Pencharz PB, Steffee WP, Cochran W, Scrimshaw NS, Rand WM, Young VR 1977 Protein metabolism in human neonates: nitrogen-balance studies, estimated obligatory losses of nitrogen and whole-body turnover of nitrogen. Clin Sci Mol Med 52:485-498

28. McCullough AJ, Mullen KD, Tavill AS, Kalhan SC 1992 In vivo differences between the turnover rates of leucine and leucine's ketoacid in stable cirrhosis. Gastroenterology 103:571-578

29. Jahoor $F$, Wolfe RR 1987 Regulation of urea production by glucose infusion in vivo. Am J Physiol 253:E543-E550

30. Stein TP, Leskiw MJ, Wallace HW, Blakemore WS 1976 The effects of insulin on urinary urea and ammonia production. J Clin Endocrinol Metab 43:18 25

31. McLean P, Novello F 1965 Influence of pancreatic hormones on enzymes concerned with urea synthesis in rat liver. Biochem J 94:410-42!

32. Picou D, Phillips M 1972 Urea metabolism in malnourished and recovered children receiving a high or low protein diet. Am J Clin Nutr 25:1261-1266 